\title{
Dynamics of dissolved and particulate organic matter during the spring bloom in the Oyashio region of the western subarctic Pacific Ocean
}

\author{
Toru Hasegawa ${ }^{1,4, *}$, Hiromi Kasai ${ }^{2}$, Tsuneo $\mathrm{Ono}^{2}$, Atsushi Tsuda ${ }^{3}$, Hiroshi Ogawa ${ }^{3}$ \\ ${ }^{1}$ Domestic Research Fellow, Japan Society for the Promotion of Science, Hokkaido National Fisheries Research Institute, \\ Fisheries Research Agency, 116, Katsurakoi, Kushiro, Hokkaido 085-0802, Japan \\ ${ }^{2}$ Hokkaido National Fisheries Research Institute, Fisheries Research Agency, 116, Katsurakoi, Kushiro, Hokkaido 085-0802, \\ Japan \\ ${ }^{3}$ Ocean Research Institute, University of Tokyo, 1-15-1, Minamidai, Nakano, Tokyo 164-8639, Japan \\ ${ }^{4}$ Present address: Seikai National Fisheries Research Institute, Fisheries Research Agency, 1551-8, Taira-machi, Nagasaki, \\ 851-2213, Japan
}

\begin{abstract}
We evaluated the dynamics of dissolved organic matter (DOM) and particulate organic matter (POM) at various stages of the spring bloom in the Oyashio region of the western subarctic Pacific Ocean by means of samples obtained during 3 cruises in April, May, and June 2003. In April, the average concentration $( \pm 1 \mathrm{SD})$ of nitrate plus nitrite ions was $23.3 \pm 0.39 \mu \mathrm{mol} \mathrm{l^{-1 }}$ in surface waters, and this decreased to below the detection limit $\left(<0.05 \mu \mathrm{mol} \mathrm{l^{-1 }}\right)$ during the bloom period. About $80 \%$ of newly accumulated organic carbon was partitioned into POM. Whereas the C:N ratios of bulk DOM ranged from 13 to 20 , the average C:N ratio of newly accumulated DOM was 7.3 \pm 1.5 . The lability of DOM was assessed by seawater culture-type incubation experiments on surface seawater samples from each observation site. Although the newly accumulated DOM was relatively rich in nitrogen, most of it escaped rapid ( $d$ to wk) bacterial consumption in the seawater culture experiments.
\end{abstract}

KEY WORDS: Dissolved organic matter · Particulate organic matter · Oyashio region · Spring bloom Resale or republication not permitted without written consent of the publisher

\section{INTRODUCTION}

Primary production in the ocean surface plays a key role in the global carbon cycle and regulates the uptake of atmospheric $\mathrm{CO}_{2}$ into the ocean. A great deal of effort has therefore gone into the precise estimation of primary production throughout the entire ocean (e.g. Longhurst et al. 1995, Polovina et al. 2008, Tilstone et al. 2009).

Photosynthesis by the planktonic community produces particulate organic carbon (POC) and dissolved organic carbon (DOC) at the surface; these 2 types of organic carbon materials have markedly different biogeochemical and ecological characteristics (Karl et al. 1998). Large particles can sink out of the surface water, and some of the POC fraction is transported by vertical migration of zooplankton (Steinberg et al. 2000, $2008 \mathrm{a}, \mathrm{b})$. DOC is mainly exported by advection and diffusion (Copin-Montégut \& Avril 1993). POC is available as a source of carbon and energy for many heterotrophs, whereas most cannot utilize DOC, which is mainly utilized by bacteria (Azam et al. 1983). Therefore, the partitioning of organic carbon production between POC and DOC is a primary constraint on marine carbon cycles.

The primary production of marine phytoplankton involves a fixed C:N ratio, known as the Redfield ratio (Redfield et al. 1963). It has been suggested that a C:N ratio of 6.6 will permit the use of the nitrogen flux as a proxy for the carbon flux; by distinguishing between new production and regenerated production it should be possible to assess carbon export production (Dug- 
dale \& Goering 1967, Eppley \& Peterson 1979). However, this simple relationship has been challenged by recent observations that more dissolved inorganic carbon than would be expected from the Redfield ratio is taken up in the euphotic layer (Sambrotto et al. 1993, Copin-Montégut 2000, Kähler \& Koeve 2001). One of the most probable consequences of this carbon overconsumption (Toggweiler 1993) is accumulation of Crich dissolved organic matter (DOM) in the surface ocean (Banse 1994, Williams 1995, Kähler \& Koeve 2001). The presence of this C-rich DOM implies that organic carbon export is decoupled from nitrogen export (Williams 1995, Hopkinson \& Vallino 2005). These studies, therefore, force us to reconsider the C:N ratios of newly accumulated organic products.

The Oyashio region of the western subarctic Pacific is a well-studied marine environment (Saito et al. 1998, Kasai et al. 2001) that has predictable seasonal cycles of primary production (Kasai 2000). It is also known that primary production in this region is comparatively high among known oceanic values (Takahashi et al. 2002). Our objective in the present study was to examine the dynamics of DOM and particulate organic matter (POM) and their $\mathrm{C}: \mathrm{N}$ ratios during the spring bloom. We also discuss the lability of DOM accumulated in surface waters.

\section{MATERIALS AND METHODS}

Sampling. The sampling program was carried out during survey cruises to the Oyashio region in 2003, along the monitoring line known as the A-line (Saito et al. 1998, Kasai et al. 2001). Along the A-line, Oyashio water coexists with the mixed water that originates partly from the subtropical Kuroshio current. Stations within the Oyashio waters were selected according to the criterion of the presence of a temperature of $<5^{\circ} \mathrm{C}$ at a depth of $100 \mathrm{~m}$ (Kawai 1972). Water samples were collected from April 15 to 16, 2003, by the RV 'Tankaimaru' and from May 17 to 22 and June 9 to 10, 2003, by the RV 'Hokko-maru'. The sampling stations were A4 $\left(42^{\circ} 15^{\prime} \mathrm{N}, 145^{\circ} 08^{\prime} \mathrm{E}\right), \mathrm{A} 5\left(42^{\circ} 00^{\prime} \mathrm{N}, 145^{\circ} 15^{\prime} \mathrm{E}\right)$, and A7 $\left(41^{\circ} 30^{\prime} \mathrm{N}, 145^{\circ} 30^{\prime} \mathrm{E}\right)$ in April; A45 $\left(42^{\circ} 08^{\prime} \mathrm{N}\right.$, $\left.145^{\circ} 11^{\prime} \mathrm{E}\right), \mathrm{A} 55\left(41^{\circ} 53^{\prime} \mathrm{N}, 145^{\circ} 19^{\prime} \mathrm{E}\right)$, and A7 in May; and A4 and A5 in June (Fig. 1).

Seawater samples were collected with a plastic bucket (surface) or a CTD rosette system equipped with 51 Niskin bottles (other depths). Samples for nutrient and DOM analyses were taken at 5 to 8 depths in the upper $500 \mathrm{~m}$ in the water column, whereas samples for POM and chlorophyll $a(\mathrm{chl} a$ ) analyses were taken at 4 to 6 depths in the upper $200 \mathrm{~m}$.

For determination of $\mathrm{NH}_{4}{ }^{+}, \mathrm{NO}_{\mathrm{x}}\left(\mathrm{NO}_{3}{ }^{-}+\mathrm{NO}_{2}{ }^{-}\right)$, $\mathrm{PO}_{4}{ }^{3-}, \mathrm{DOC}$, and dissolved organic nitrogen (DON), a

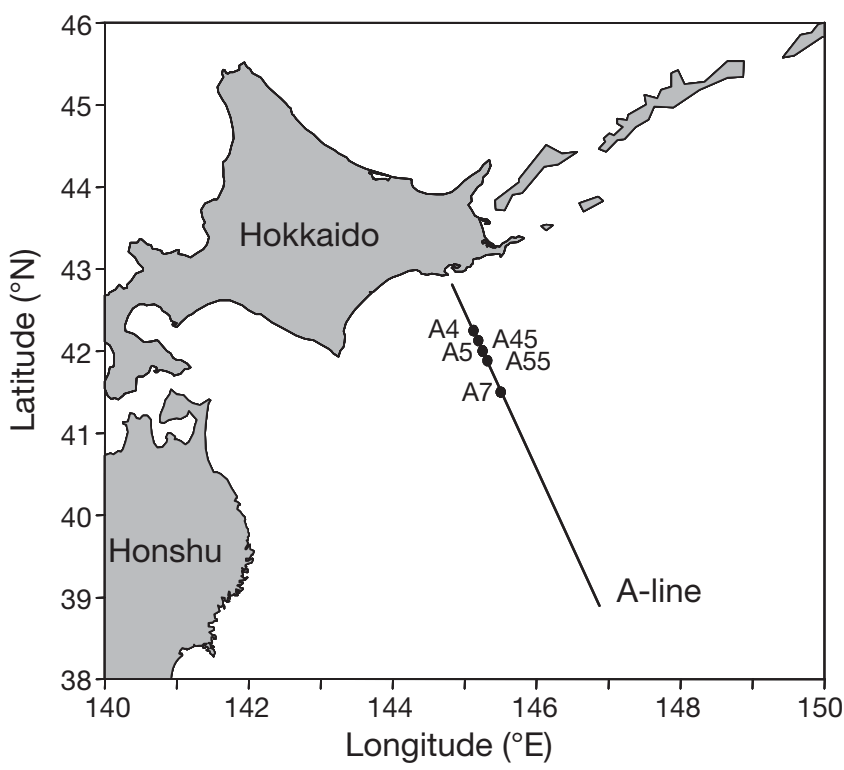

Fig. 1. Study site of the Oyashio region in the western subarctic Pacific. Solid line shows the monitoring line (A-line)

subsample $(100 \mathrm{ml})$ was GF/F filtered $(47 \mathrm{~mm}$; precombusted at $450^{\circ} \mathrm{C}, 3 \mathrm{~h}$ ), and the filtrate was frozen for subsequent analyses in a $20 \mathrm{ml}$ glass vial (precombusted at $550^{\circ} \mathrm{C}, 5 \mathrm{~h}$ ). For the analyses of POC and particulate organic nitrogen (PON), a subsample (1000 to $2000 \mathrm{ml}$ ) was GF/F filtered ( $47 \mathrm{~mm}$; precombusted at $450^{\circ} \mathrm{C}, 3 \mathrm{~h}$ ), and the filter was frozen until its carbon and nitrogen contents were determined. For chl a analysis, a subsample (120 ml) was GF/F filtered (25 $\mathrm{mm}$ ) and stored with $\mathrm{N}, \mathrm{N}$-dimethylformamide at $-20^{\circ} \mathrm{C}$. Vacuum-filtration onto a $\mathrm{GF} / \mathrm{F}$ filter was performed at a pressure of $<50 \mathrm{~mm} \mathrm{Hg}$ to minimize cell disruption.

Seawater culture experiments. To evaluate the lability of DOM, seawater culture-type incubation experiments were performed by using surface seawater $(0 \mathrm{~m})$ from each observation site. The filtrate from a $47 \mathrm{~mm}$ $\mathrm{GF} / \mathrm{F}$ filter (precombusted at $450^{\circ} \mathrm{C}, 3 \mathrm{~h}$ ) was dispensed into 6 or 7 Teflon bottles that had been acidwashed and rinsed thoroughly with Milli-Q water before use. The samples were then incubated in darkness at $5^{\circ} \mathrm{C}$. Although the incubation experiments were performed at $5^{\circ} \mathrm{C}$, the surface seawater temperatures ranged from 1.6 to $7.5^{\circ} \mathrm{C}$. However, the effect of the temperature on the estimation of the lability of DOC is likely to be minimal, because the incubation periods were long (15 to $38 \mathrm{~d}$ ) and most of the labile DOC would have been consumed. Samplings were performed at intervals of 0.5 to $21 \mathrm{~d}$ (see Fig. 5). At each sampling stage (including Day 0), 1 bottle was used as a sample for DOC analyses and bacterial counts. For determination of $\mathrm{NH}_{4}{ }^{+}, \mathrm{NO}_{\mathrm{x}} \mathrm{PO}_{4}{ }^{3-}, \mathrm{DOC}$, and DON, subsamples were frozen for later analyses in 
$20 \mathrm{ml}$ glass vials (precombusted at $550^{\circ} \mathrm{C}, 5 \mathrm{~h}$ ) without filtration. For bacterial counts, subsamples $(10 \mathrm{ml})$ were fixed with formalin (final concentration $1 \%$ ) and stored at $4^{\circ} \mathrm{C}$.

Chemical and bacterial analyses. Concentrations of $\mathrm{NH}_{4}{ }^{+}, \mathrm{NO}_{\mathrm{x}}$, and $\mathrm{PO}_{4}{ }^{3-}$ were measured with a Bran + Luebbe Autoanalyzer III using a modified version of the method of Strickland \& Parsons (1972). Concentrations of DOC and total dissolved nitrogen (TDN) were measured using a high-temperature catalytic oxidation method with a modified Shimadzu TOC-5000 unit, according to the method of Ogawa et al. (1999). Glucose and potassium nitrate were used as standards for DOC and TDN, respectively. Typical blank values for DOC and TDN analyses (i.e. values for Milli-Q water) were 3.2 to $5.5 \mu \mathrm{mol} \mathrm{l} \mathrm{l}^{-1}$ and 0.6 to $1.0 \mu \mathrm{mol} \mathrm{l}^{-1}$, respectively. Replicate analyses (usually 4 instances) were performed continuously for each sample. The DOC and TDN were measured with average standard deviations of 0.7 and $0.3 \mu \mathrm{mol} \mathrm{^{-1 }}$, respectively. DON concentrations were calculated by subtracting the concentrations of $\mathrm{NH}_{4}{ }^{+}$and $\mathrm{NO}_{\mathrm{x}}$ from those of TDN. The concentrations of POC and PON were measured by means of a CHN analyzer (MT-5, Yanaco). Before this analysis, the GF/F filter was acidified with $\mathrm{HCl}$ vapor to remove carbonate. Chl a concentrations were determined by the fluorometric method of Strickland \& Parsons (1972), as modified by Suzuki \& Ishimaru (1990), using a Turner Designs fluorometer. Bacteria were counted directly by means of epifluorescence microscopy after staining with DAPI (Porter \& Feig 1980).

\section{RESULTS}

\section{Vertical profiles of sigma-t, $\mathrm{NO}_{\mathrm{x}}, \mathrm{chl} \mathrm{a}_{\mathrm{r}}$ and organic carbon}

Sea surface temperature ranged from 1.7 to $2.7^{\circ} \mathrm{C}$ in April, from 3.6 to $5.6^{\circ} \mathrm{C}$ in May, and from 6.0 to $8.1^{\circ} \mathrm{C}$ in June. The sea surface salinity ranged from 33.0 to 33.1 in April, from 32.8 to 32.9 in May (no data for A45), and from 32.7 to 32.9 in June. In April, sigma-t values were distributed almost uniformly through the upper $100 \mathrm{~m}$ at all stations, suggesting that the waters were vertically and horizontally well-mixed at that time (Fig. 2, upper panels). In this region, good mixing of the waters in the upper $100 \mathrm{~m}$ have also been observed during March to April in other years (Saito et al. 1998, Kasai et al. 2001). The high concentrations of $\mathrm{NO}_{\mathrm{x}}(23.3 \pm$ $\left.0.39 \mu \mathrm{mol} \mathrm{l}^{-1}\right)$ and the low concentrations of chl a $(0.31$ $\pm 0.035 \mu \mathrm{g} \mathrm{l}^{-1}$ ) at the surface showed that April was a pre-bloom period. The DOC and POC concentrations at the surface were $54.1 \pm 1.5 \mu \mathrm{mol} \mathrm{l^{-1 }}$ and $6.0 \pm$ $1.1 \mu \mathrm{mol} \mathrm{l}^{-1}$, respectively (Figs. $2 \& 3$ ).
Later, the sigma-t values and $\mathrm{NO}_{\mathrm{x}}$ concentrations gradually decreased in the shallow layers (Fig. 2, middle and lower panels). As the $\mathrm{NO}_{\mathrm{x}}$ concentration decreased, the DOC and POC concentrations increased (Figs. 2 \& 3). In June, the POC concentrations decreased to $<20 \mu \mathrm{mol}{ }^{-1}$ at station A4 (Fig. 3, lower panels). During the observation period, many concentration changes were observed at depths of $<20$ m (Figs. 2 $\& 3)$. An explanation for the changes in the above parameters following decreases in $\mathrm{NO}_{\mathrm{x}}$ concentrations is given in the next section. The progress of blooming was arbitrarily divided into 3 phases corresponding to various $\mathrm{NO}_{\mathrm{x}}$ concentrations, i.e. pre-bloom $\left(\mathrm{NO}_{\mathrm{x}} 23.3 \pm\right.$ $\left.0.39 \mu \mathrm{mol} \mathrm{l} \mathrm{l}^{-1}\right)$, bloom $\left(\mathrm{NO}_{\mathrm{x}} 0.63\right.$ to $\left.11.6 \mu \mathrm{mol} \mathrm{l} \mathrm{l}^{-1}\right)$, and post-bloom $\left(\mathrm{NO}_{\mathrm{x}}<0.05 \mu \mathrm{mol} \mathrm{l^{-1 }}\right)$.

\section{Changes in chl a, DOM and POM}

Relationships between $\mathrm{NO}_{\mathrm{x}}$ and chl a concentrations in the shallow layer (depth $<20 \mathrm{~m}$ ) during the observation period are shown in Fig. 4a. The shallow layer was considered to be the euphotic layer during most of the observation period ( $\mathrm{H}$. Kasai unpubl. data). As the blooming condition progressed, the $\mathrm{NO}_{\mathrm{x}}$ concentration decreased from 23.3 to $11.5 \mathrm{\mu mol} \mathrm{l}^{-1}$, and the chl a concentration increased from 0.31 to $10.5 \mathrm{\mu g} \mathrm{l}^{-1}$ (Fig. 4a). Later, the chl a concentrations were relatively high (5.9 to $9.1 \mu \mathrm{g} \mathrm{l}^{-1}$ ), and they ranged from 0.67 to $4.2 \mu \mathrm{g} \mathrm{l}^{-1}$ when the $\mathrm{NO}_{\mathrm{x}}$ concentration was $<0.63 \mu \mathrm{mol} \mathrm{l} \mathrm{l}^{-1}$. When $\mathrm{NO}_{\mathrm{x}}$ concentrations were $<0.05 \mu \mathrm{mol} \mathrm{l}^{-1}$ at the surface, the $\mathrm{NH}_{4}{ }^{+}$concentrations were also $<0.05 \mu \mathrm{mol} \mathrm{l} \mathrm{l}^{-1}$, but the $\mathrm{PO}_{4}{ }^{3-}$ concentrations were $>0.1 \mu \mathrm{mol} \mathrm{l}^{-1}$, suggesting that $\mathrm{N}$-limited conditions existed in the regions that we studied.

The relationships between shallow-layer $\mathrm{NO}_{\mathrm{x}}$ concentrations and those of organic matter are also shown in Fig. 4b,c. The concentrations of both carbon and nitrogen in the DOM were higher than those in the POM during the pre-bloom period. As $\mathrm{NO}_{\mathrm{x}}$ was consumed, the concentrations of both types of organic matter increased, and the magnitudes of the increases were much greater for the particles (Fig. 4b,c). POM concentrations frequently exceeded those of DOM in the nitrogen pool, but not in the carbon pool.

To calculate the concentrations of newly accumulated POM and DOM, the average pre-bloom POM and DOM concentrations were subtracted from the corresponding observed POM and DOM concentrations (Table 1, Fig. 4b,c). Under bloom conditions, the proportions of newly accumulated POC and PON were $78 \pm 16 \%$ and $81 \pm 16 \%$, respectively, of the total concentrations (newly accumulated POM + DOM), and these values decreased to $65 \pm 15 \%$ and $62 \pm 17 \%$, respectively, under post-bloom conditions (Table 1). 


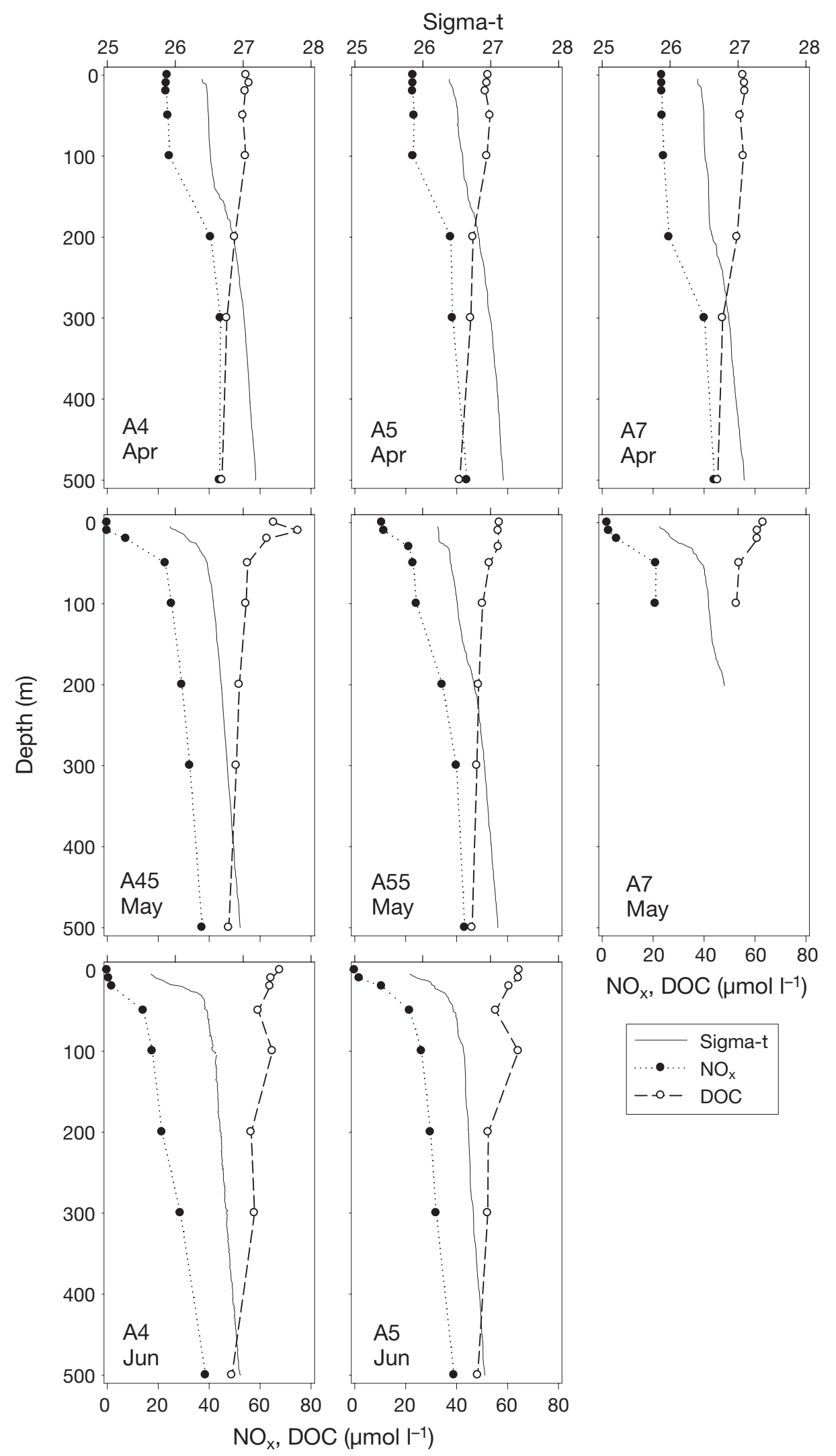

Fig. 2. Vertical distributions of sigma-t and concentrations of $\mathrm{NO}_{\mathrm{x}}\left(\mathrm{NO}_{3}{ }^{-}+\mathrm{NO}_{2}{ }^{-}\right)$and dissolved organic carbon (DOC) at 3 (April and May) or 2 (June) sampling stations. Upper, middle, and lower panels correspond to measurements taken in April, May, and June, respectively 


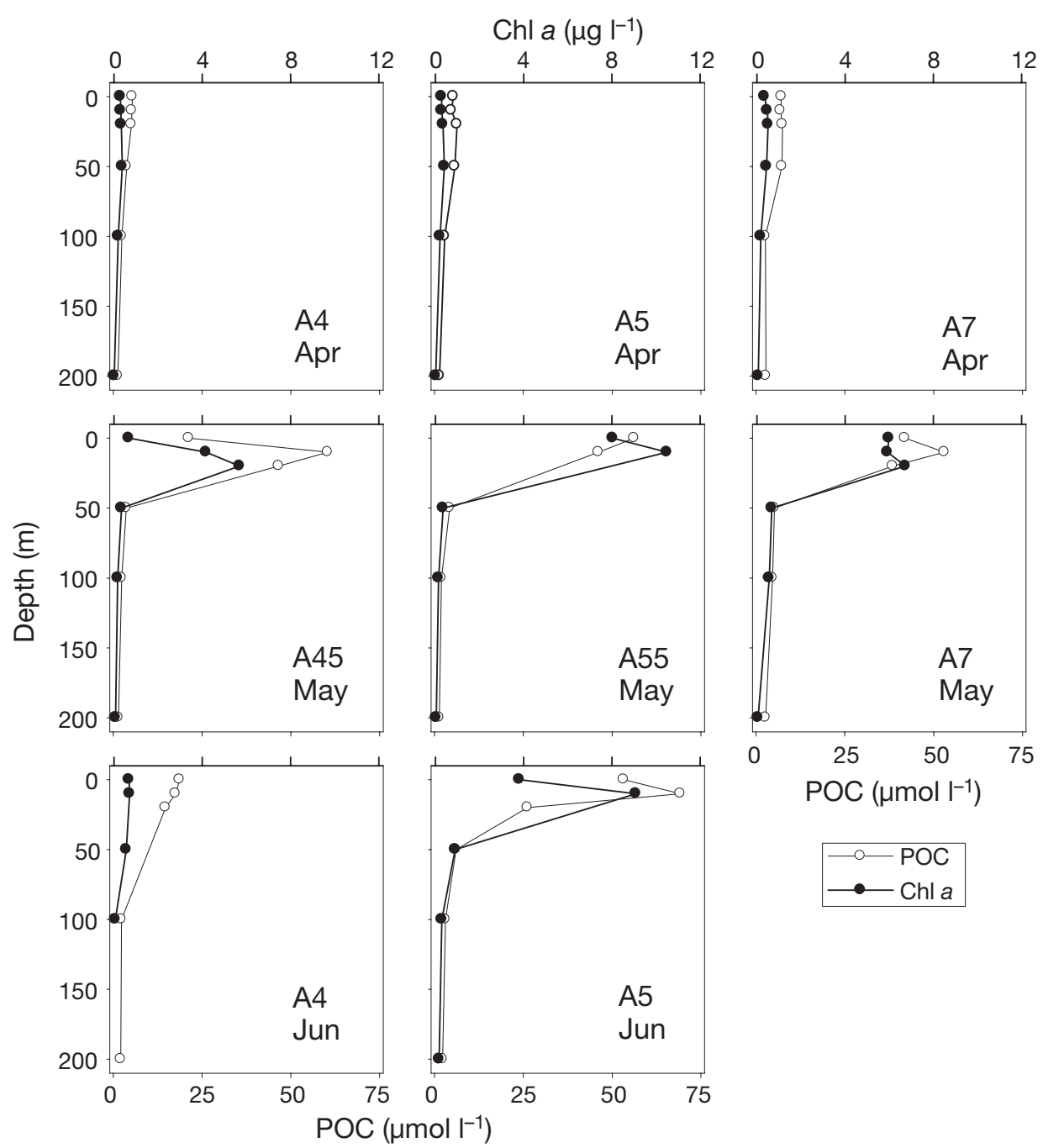

Fig. 3. Vertical distributions of concentrations of particulate organic carbon (POC) and chlorophyll a (chl a) at 3 (April and May) or 2 (June) sampling stations. Upper, middle, and lower panels correspond to measurements for April, May, and June, respectively

In the pre-bloom period, the average $\mathrm{C}: \mathrm{N}$ ratio for POM was $6.0 \pm 0.30$. Under bloom and post-bloom conditions, the $\mathrm{C}: \mathrm{N}$ ratios were $5.9 \pm 0.51$ and $8.7 \pm 0.62$, respectively, and the averages were significantly different (Kruskal-Wallis test, $\mathrm{p}<0.01$ ). The average $\mathrm{C}: \mathrm{N}$ ratios of DOM were $15.9 \pm 2.2,13.9 \pm 1.4$, and $13.5 \pm 0.83$ in the pre-bloom, bloom, and post-bloom periods, respectively, and the decrease in the value is significant (KruskalWallis test, $\mathrm{p}<0.05$ ); however, the ratios exceeded the Redfield ratio throughout the observation period.

\section{Seawater culture experiment}

Seawater culture experiments were performed using surface seawater samples $(0 \mathrm{~m})$ that were $\mathrm{GF} / \mathrm{F}$ filtered at the start of the incubation. Filtration removed 69 to $85 \%$ of bacterial cells from the original seawater. The changes in the DOC concentrations and bacterial cell numbers that occurred during incubation experiments are shown in Fig. 5. The numbers of bacterial cells increased 2- to 7-fold, and exponential growth appeared to be complete before Day 20. Relatively small changes were observed for DOC concentrations during the incubation periods, and the maximum

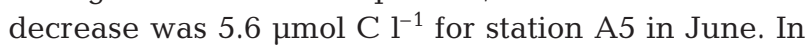
the all cases, the major decrease in DOC concentration occurred within the first few days of incubation (Fig. 5).

\section{DISCUSSION}

\section{Organic carbon partitioning and $\mathrm{C}: \mathrm{N}$ ratios of dissolved organic matter}

The spring phytoplankton bloom resulted in an accumulation of organic matter in the shallow region. POC and DOC concentrations increased by up to 12 -fold 

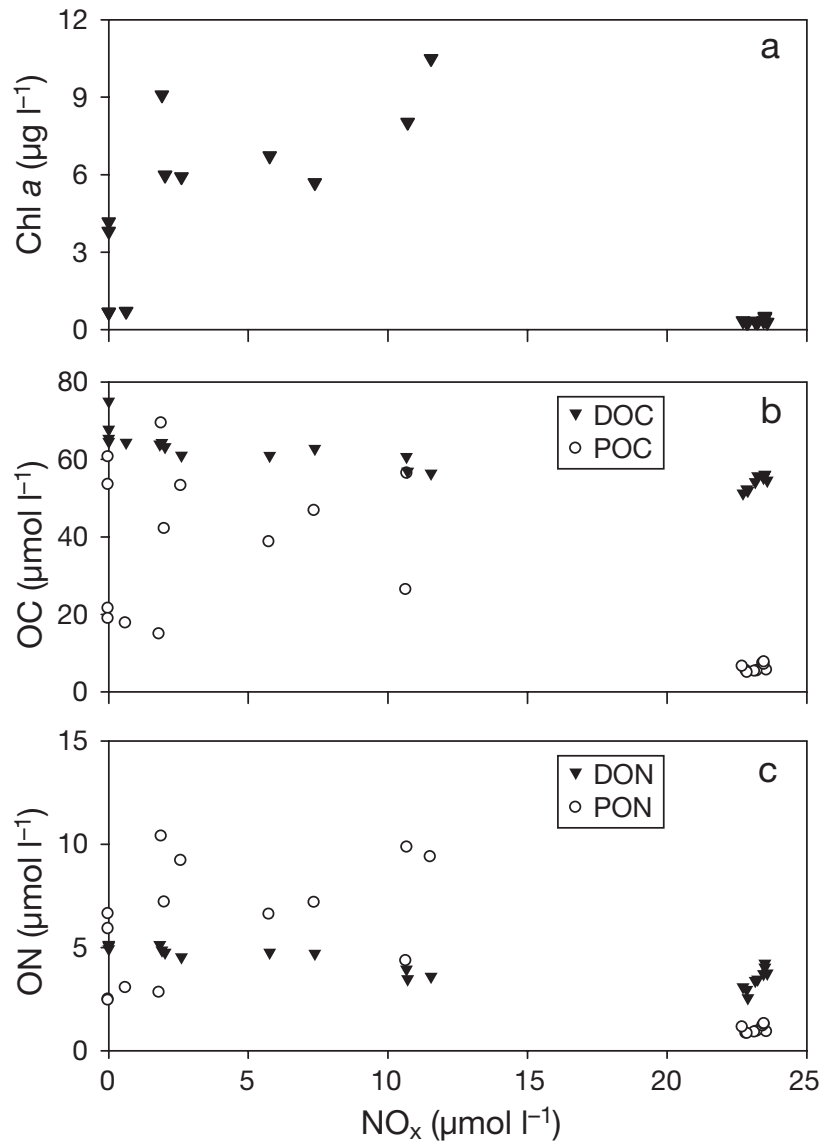

Fig. 4. Relationships between surface layer $\mathrm{NO}_{\mathrm{x}}\left(\mathrm{NO}_{3}{ }^{-}+\right.$ $\mathrm{NO}_{2}^{-}$) and (a) chl a: chlorophyll $a$, (b) OC: organic carbon, and (c) ON:organic nitrogen. DOC: dissolved organic carbon; POC: particulate organic carbon; PON: particulate organic nitrogen; DON: dissolved organic nitrogen

and 1.4-fold, respectively (Fig. 4b,c). In this region, 47 to $95 \%$ (average $78 \%$ ) of newly accumulated organic carbon was partitioned into particulate forms in the bloom (Table 1).
In agreement with the results of our study, Carlson et al. (1998) have shown that $89 \%$ of newly accumulated organic carbon during a bloom in the Ross Sea was present as POC (Table 2). Körtzinger et al. (2001) have also shown the importance of POC (66 to 100\%) as newly accumulated organic carbon in the northeast Atlantic Ocean. Conversely, some studies have reported that accumulation of DOC was of the same magnitude as that of POC or that it exceeded that of POC during the bloom period. In the English Channel, $83 \%$ of newly accumulated carbon in the surface water was present as DOC (Williams 1995). In the Sargasso Sea, the average of newly accumulated DOC was $86 \%$ in 1992, 1993, and 1995, whereas from 1996 to 2000, it was 47 \% (Carlson et al. 1998, Lomas \& Bates 2004).

These studies clearly show the existence of large spatial and temporal variations in the proportion of newly accumulated POC to total newly accumulated organic carbon. However, the variations cannot be explained in terms of the region (oceanic or coastal) or the dominant phytoplankton (Table 2). For example, in the Sargasso Sea, although Haptophytes dominated throughout the period that was studied, the percentage of newly accumulated POC increased considerably after 1995 (Lomas \& Bates 2004; Table 2).

It has been suggested that healthy cells of phytoplankton release some 0 to $10 \%$ of their primary production as DOC (Sharp 1977, Smith et al. 1977, Mague et al. 1980), and therefore, phytoplankton in both the English Channel and the Sargasso Sea could have been stressed by nutrient limitation (Lancelot 1983) and/or extreme irradiance (Zlotnik and Dubinsky 1989). Also, the release of DOC mediated by heterotrophs and viruses (Nagata 2000) could be dominant.

Generally, C:N ratios for bulk DOM are considerably higher than the Redfield ratio, and in surface ocean, a typical C:N ratio of 14 has been reported (Benner

Table 1. Average $( \pm \mathrm{SD})$ concentrations $\left(\mu \mathrm{mol} \mathrm{l}^{-1}\right)$ of particulate organic carbon (POC), dissolved organic carbon (DOC), particulate organic nitrogen (PON), and dissolved organic nitrogen (DON). Phases were arbitrarily divided by correspondence to $\mathrm{NO}_{\mathrm{x}}$ concentrations in the same seawater, i.e. pre-bloom $\left(\mathrm{NO}_{\mathrm{x}}: 23.3 \pm 0.39 \mu \mathrm{mol} \mathrm{l}^{-1}\right)$, bloom $\left(\mathrm{NO}_{\mathrm{x}}: 0.63\right.$ to $\left.11.6 \mu \mathrm{mol} \mathrm{l}^{-1}\right)$, and post-bloom $\left(\mathrm{NO}_{\mathrm{x}}:<0.05 \mu \mathrm{mol} \mathrm{l^{-1 }}\right.$ ). Values in parentheses represent concentrations of newly accumulated POC, DOC, PON, and DON (estimated by subtracting the average pre-bloom POC, DOC, PON and DON concentrations from the corresponding observed POC, DOC, PON and DON concentrations) and the proportions of newly accumulated POC and PON are expressed as percentages of total newly accumulated organic carbon and nitrogen, respectively

\begin{tabular}{|c|c|c|c|c|c|c|c|}
\hline Phase & $\begin{array}{c}\text { POC } \\
\left(\mu \mathrm{mol} \mathrm{l}^{-1}\right)\end{array}$ & $\begin{array}{c}\text { DOC } \\
\left(\mu \mathrm{mol} \mathrm{l}^{-1}\right)\end{array}$ & $\begin{array}{c}\text { POC } \\
(\%)\end{array}$ & $\begin{array}{c}\text { PON } \\
\left(\mu \mathrm{mol} \mathrm{l^{-1 }}\right)\end{array}$ & $\begin{array}{c}\text { DON } \\
\left(\mu \mathrm{mol} \mathrm{l}^{-1}\right)\end{array}$ & $\begin{array}{l}\mathrm{PON} \\
(\%)\end{array}$ & $\mathrm{n}$ \\
\hline Pre-bloom & $6.0 \pm 1.0$ & $54.2 \pm 1.9$ & & $1.0 \pm 0.19$ & $3.5 \pm 0.53$ & & 6 \\
\hline $\begin{array}{l}\text { Bloom } \\
\text { (Newly accumulated) }\end{array}$ & $\begin{array}{c}41.0 \pm 17.3 \\
(35.0 \pm 17.3)\end{array}$ & $\begin{array}{l}61.5 \pm 2.9 \\
(7.3 \pm 2.9)\end{array}$ & $(78 \pm 16)$ & $\begin{array}{l}7.0 \pm 2.8 \\
(6.0 \pm 2.8)\end{array}$ & $\begin{array}{c}4.5 \pm 0.60 \\
(1.0 \pm 0.60)\end{array}$ & $(81 \pm 16)$ & $\begin{array}{c}10 \\
(10)\end{array}$ \\
\hline $\begin{array}{l}\text { Post-bloom } \\
\text { (Newly accumulated) }\end{array}$ & $\begin{array}{c}38.5 \pm 21.5 \\
(32.5 \pm 21.5)\end{array}$ & $\begin{array}{c}68.2 \pm 4.7 \\
(14.0 \pm 4.7)\end{array}$ & $(65 \pm 15)$ & $\begin{array}{c}4.3 \pm 2.2 \\
(3.3 \pm 2.2)\end{array}$ & $\begin{array}{c}5.1 \pm 0.08 \\
(1.6 \pm 0.08)\end{array}$ & $(62 \pm 17)$ & $\begin{array}{c}4 \\
(4)\end{array}$ \\
\hline
\end{tabular}



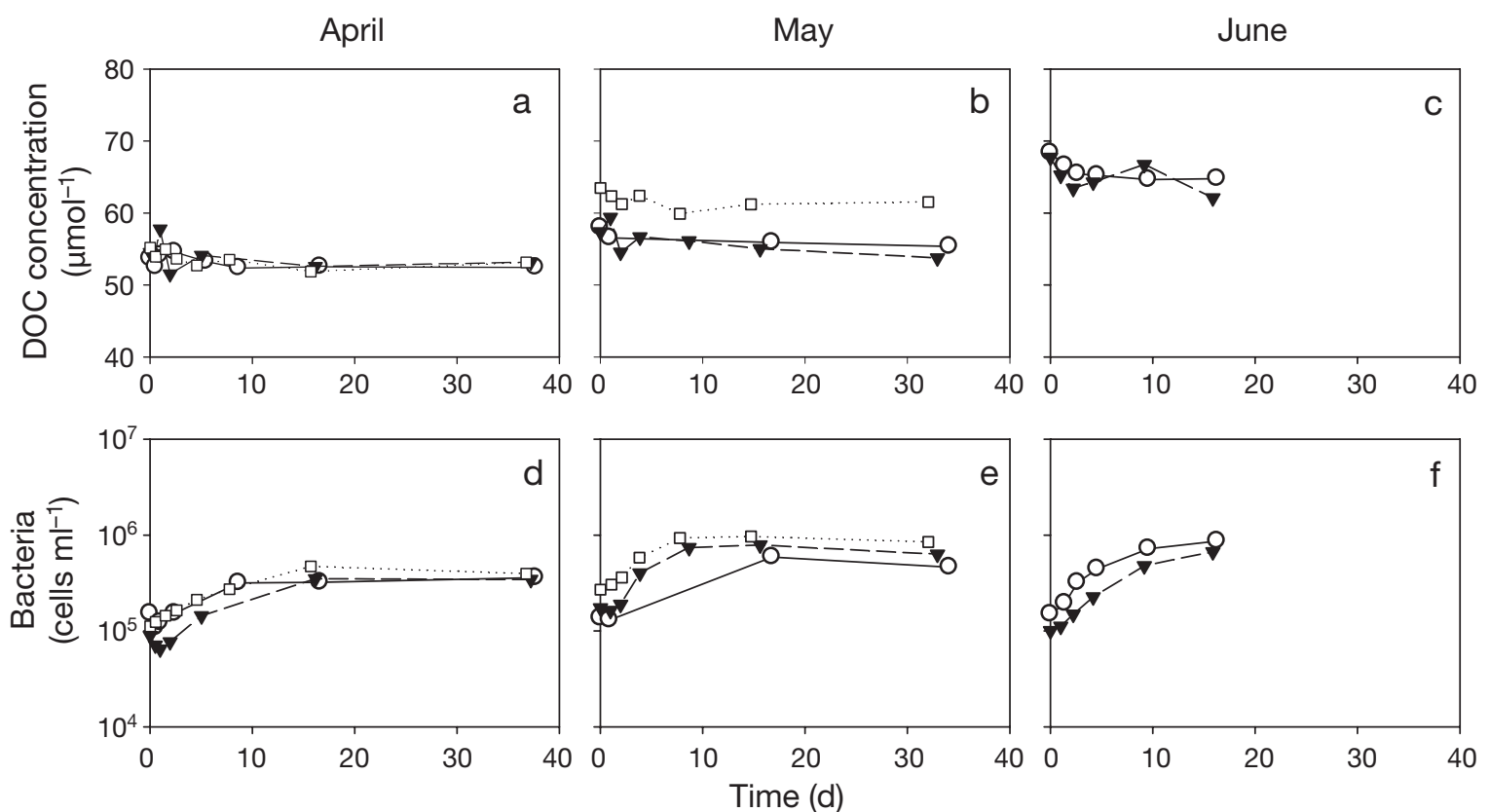

Fig. 5. $(\mathrm{a}-\mathrm{c})$ Dissolved organic carbon (DOC) concentrations and $(\mathrm{d}-\mathrm{f})$ bacterial cell numbers during the seawater culture experi-

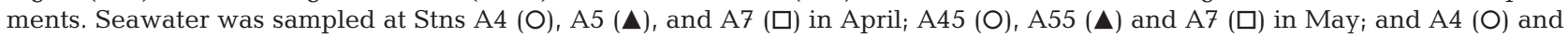
A5 (A) in June

2002). However, a wide range of ratios is known to exist for newly accumulated DOM (Table 2). Hopkinson \& Vallino (2005) showed relatively high ratios of 9.8 for the Georges Bank and 10 to 14 for the middle Atlantic Bight. Very high C:N ratios of accumulated DOM (up to 25) have been reported for the English
Channel and the north Atlantic Ocean (Williams 1995, Körtzinger et al. 2001).

In contrast to the above, the average $\mathrm{C}: \mathrm{N}$ ratio of newly accumulated DOM was 6.2 in the southern Ross Sea (Carlson et al. 2000), 8.4 in the East China Sea (Hung et al. 2003), and 8.7 the Hawaiian Ocean (Hop-

Table 2. Proportions of newly accumulated particulate organic carbon (POC) to total newly accumulated organic carbon, expressed as percentages, and the C:N ratios of the newly accumulated dissolved organic matter (DOM). Numbers in parentheses are ranges or $\mathrm{SD}$

\begin{tabular}{|c|c|c|c|c|c|}
\hline Site & POC (\%) & $\mathrm{C}: \mathrm{N}$ ratio & $\begin{array}{l}\text { Dominant } \\
\text { phytoplankton }\end{array}$ & Description & Source \\
\hline Ross Sea & 89 & 6.2 & Phaeocystis & Oceanic region & $\begin{array}{l}\text { Carlson et al. (1998) } \\
\text { Carlson et al. (2000) }\end{array}$ \\
\hline Northeast Atlantic Ocean & $84(66-100)$ & $24(23-25)$ & $\begin{array}{l}\text { Diatom flagellates } \\
\text { (ultraplankton) }\end{array}$ & Oceanic region & Körtzinger et al. (2001) \\
\hline English Channel & 17 & 20 & & Coastal region & Williams (1995) \\
\hline Sargasso Sea & $\begin{array}{l}14(9.5-22) \\
53(38-100)\end{array}$ & & $\begin{array}{l}\text { Haptophytes } \\
\text { Haptophytes }\end{array}$ & $\begin{array}{l}\text { Oceanic region } \\
\text { in } 1992,1993, \\
\text { and } 1995 \\
\text { Oceanic region } \\
\text { from } 1996 \text { to } 2000\end{array}$ & $\begin{array}{l}\text { Carlson et al. (1998) } \\
\text { Lomas \& Bates (2004) } \\
\text { Lomas \& Bates (2004) }\end{array}$ \\
\hline Georges Bank & & $9.8(1.4)$ & & Coastal region & Hopkinson \& Vallino (2005) \\
\hline Middle Atlantic Bight & & $10(0.9)-14(0.6)$ & & Coastal region & Hopkinson \& Vallino (2005) \\
\hline East China Sea & & 8.4 & & Coastal region & Hung et al. (2003) \\
\hline Hawaiian Ocean & & $8.7(0.6)$ & & Oceanic region & Hopkinson \& Vallino (2005) \\
\hline Southern Ocean & & $2.7(1.7)-52(49)$ & & Oceanic region & Ogawa et al. (1999) \\
\hline $\begin{array}{l}\text { Subarctic western North } \\
\text { Pacific }\end{array}$ & $74^{\mathrm{a}}(47-95)$ & $7.3 \pm 1.5^{\mathrm{b}}$ & Diatoms ${ }^{c}$ & Oceanic region & Present study \\
\hline
\end{tabular}




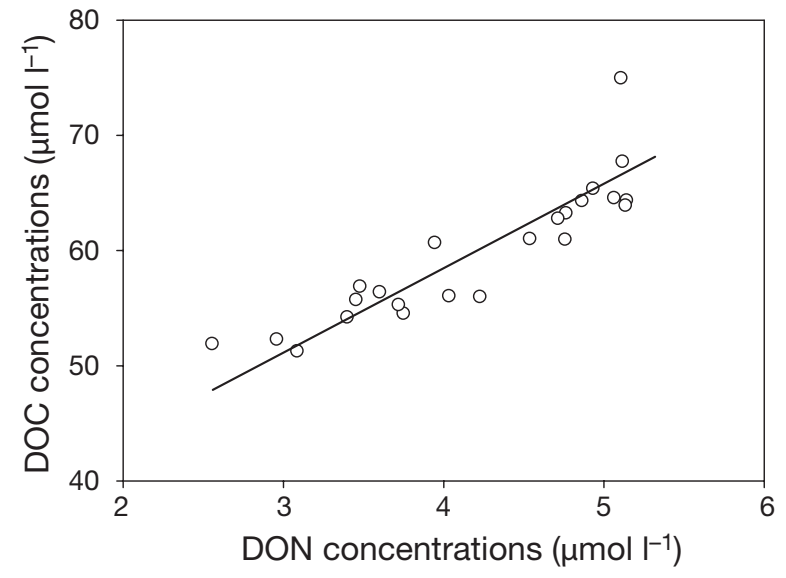

Fig. 6. Relationship between dissolved organic nitrogen (DON) and carbon (DOC) concentrations. Solid line is the regression (Model II) line. Resulting slope $( \pm 95 \%$ confidence interval $)$ is $7.3 \pm 1.5\left(\mathrm{n}=23, \mathrm{R}^{2}=0.80, \mathrm{p}<0.01\right)$

kinson \& Vallino 2005). In the present study, the property-property plot for DON and DOC in the shallow layer $(<20 \mathrm{~m}$ depth) suggests that the average $\mathrm{C}: \mathrm{N}$ ratio of newly accumulated DOM was $7.3 \pm 1.5$ (the slope of Model II regression; $\mathrm{n}=23, \mathrm{p}<0.01$; Fig. 6 and Table 2).

Although, C:N ratios for newly accumulated DOM showed a considerable degree of variation (Table 2), the ratios were all lower than the bulk C:N ratio of 14 that is typically found near the surface of oceans (Table 2, Benner 2002), except for the northeast Atlantic Ocean and the English Channel. The bulk C:N ratios were lower in surface waters than in deep waters, implying that nitrogenous compounds undergo selective decomposition during the downward transport of DOM (Benner 2002, Ogawa \& Tanoue 2003). It is likely that selective decomposition also partially explains the lower $\mathrm{C}: \mathrm{N}$ ratios of newly accumulated DOM in comparison with the $\mathrm{C}: \mathrm{N}$ ratio for typical bulk DOM in surface waters.

Hopkinson \& Vallino (2005) suggested that, for a given mass of new nitrogen entering the surface layer, newly accumulated DOM enriched with carbon can efficiently export more carbon than would be expected from the Redfield stoichiometry. However, the C:N ratios of newly accumulated DOM showed a wide range of values (Table 2); the efficiency of export may therefore change accordingly.

\section{Bacterial use of newly accumulated DOC}

DOC can, conceptually, be partitioned into 3 pools: labile, semi-labile, and refractory (Kirchman et al. 1993). These have turnover times of hours to days, months to years, and centuries to millennia, respectively. This concept provides us with information on the lability of DOC on the basis of the vertical profile of DOC concentrations (Carlson 2002). In the pre-bloom period, the average DOC concentration of the upper $100 \mathrm{~m}$ was $54 \pm 1.6 \mu \mathrm{mol} \mathrm{l^{-1 }}$, and the vertical profiles suggest that at least about $10 \mu \mathrm{mol} \mathrm{l}^{-1}$ of labile to semilabile DOC persisted in the surface waters (Fig. 2). The value of $10 \mu \mathrm{mol} \mathrm{l} \mathrm{l}^{-1}$ is the excess DOC concentration compared with the value at a depth of $500 \mathrm{~m}(44 \pm 2.3$ $\mu \mathrm{mol} \mathrm{l}^{-1}$ ).

DOC concentrations in the surface layers increased to $75 \mu \mathrm{mol} \mathrm{l}^{-1}$ during the bloom periods (Fig. 2). Other studies have also shown that DOC accumulation occurs in the upper water column during and/or after the productive season (Copin-Montégut \& Avril 1993, Carlson et al. 1994, Williams 1995, Sohrin \& Sempéré 2005, Mathis et al. 2007). These results suggest that decoupling occurs between DOC production and the consumption of DOC by bacteria.

Whereas recent studies suggest that the levels of biomolecules such as polyunsaturated fatty acids and amino acids are predictors of the bacterial availability of DOM (McCallister et al. 2006, Davis \& Benner 2007), seawater culture-type experiments are a common and direct method for assaying the utilization of DOM by bacteria. Our seawater culture experiments showed that a small proportion of the bulk DOC pool consisted

Table 3. Range of initial and consumed dissolved organic carbon (DOC) concentrations, initial dissolved inorganic nitrogen (DIN) and PO ${ }_{4}^{3-}$ concentrations, DOC consumption rate, percentages of consumed DOC fraction, increases in bacterial cells, increased bacterial carbon, and bacterial growth efficiencies (BGE) in the seawater culture experiments. All incubation experiments were performed in darkness at $5^{\circ} \mathrm{C}$

\begin{tabular}{|c|c|c|c|c|c|c|c|c|c|c|}
\hline Month & $\begin{array}{c}\text { Initial DOC } \\
\left(\mu \mathrm{mol} \mathrm{l} \mathrm{l}^{-1}\right)\end{array}$ & $\begin{array}{c}\text { Consumed } \\
\text { DOC }\left(\mu m o l l^{-1}\right)\end{array}$ & $\begin{array}{c}\text { Initial DIN } \\
\left(\mu \mathrm{mol} \mathrm{l} \mathrm{l}^{-1}\right)\end{array}$ & $\begin{array}{c}\text { Initial } \\
\mathrm{PO}_{4}^{3-} \\
\left(\mu \mathrm{mol} \mathrm{l}^{-1}\right)\end{array}$ & $\begin{array}{c}\text { DOC } \\
\text { consumption } \\
\operatorname{rate}^{\mathrm{a}}\left(\mu \mathrm{mol}^{-1} \mathrm{~d}^{-1}\right)\end{array}$ & $\begin{array}{c}\text { DOC } \\
\text { consumed } \\
(\%)\end{array}$ & $\begin{array}{c}\text { Increase in } \\
\text { bacteria } \\
\left(10^{5} \text { cells } \mathrm{ml}^{-1}\right)\end{array}$ & $\begin{array}{c}\text { Increased } \\
\text { bacterial } \\
\mathrm{C}^{\mathrm{b}} \\
\left(\mu \mathrm{mol} \mathrm{l}{ }^{-1}\right)\end{array}$ & $\begin{array}{c}\mathrm{BGE}^{\mathrm{b}} \\
(\%)\end{array}$ & $\mathrm{n}$ \\
\hline April & $53.7-55.2$ & $1.1-3.3$ & $23.0-23.9$ & 1.9 & $0.08-0.17$ & $2.1-6.0$ & $1.7-3.6$ & $0.17-0.35$ & $9.8-13.0$ & 3 \\
\hline May & $58.0-63.5$ & $2.1-2.3$ & $1.8-14.1$ & $0.3-1.3$ & $0.09-0.15$ & $3.6-4.1$ & $4.5-6.9$ & $0.45-0.69$ & $17.7-23.3$ & 3 \\
\hline June & $67.7-68.4$ & $3.6-5.6$ & $3.6-5.6$ & $0.1-0.2$ & $0.16-0.18$ & $5.3-8.3$ & $5.7-7.1$ & $0.57-0.71$ & $9.2-16.6$ & 2 \\
\hline
\end{tabular}


of labile DOC ; this was the DOC consumed during 15 to $17 \mathrm{~d}$ (within the period of exponential bacterial growth). The concentrations of labile DOC ranged from 1.1 to $5.6 \mu \mathrm{mol} \mathrm{l}^{-1}$ (Table 3, Fig. 5). As bacteria were only removed at the start of incubation, DOC consumption was underestimated according to the increased bacterial carbon.

During 15 to $17 \mathrm{~d}$ of incubation, increases in bacteria ranged from $1.7 \times 10^{5}$ to $7.1 \times 10^{5}$ cells ml $^{-1}$ (Table 3 , Fig. 5). Assuming an oceanic bacterial carbon content of $12 \mathrm{fg} \mathrm{C} \mathrm{Cell}^{-1}$ (Ducklow 2000), the increases in bacterial carbon were 0.17 to $0.35 \mu \mathrm{mol} \mathrm{l}^{-1}$ in April, 0.45 to $0.69 \mu \mathrm{mol} \mathrm{l}^{-1}$ in May, and 0.57 to $0.71 \mu \mathrm{mol} \mathrm{l^{-1 }}$ in June (Table 3). Total labile DOC concentrations (consumed DOC + increased bacterial carbon) ranged from 1.3 to $6.2 \mu \mathrm{mol} \mathrm{^{-1 }}$. Also, by using an oceanic bacterial carbon content of $12 \mathrm{fg} \mathrm{C} \mathrm{Cell}^{-1}$, the values of the bacterial growth efficiency (BGE) were estimated to be 9.8 to $13 \%$ in April, 18 to $23 \%$ in May, and 9.2 to $17 \%$ in June (Table 3), which are within the range of reported values for marine bacteria (del Giorgio \& Cole 2000).

BGE is likely to increase with increasing primary production (del Giorgio \& Cole 2000). Eichinger et al. (2006) showed that BGE is higher in surface layers (5 m) than in deep layers (200 and $400 \mathrm{~m}$ ), and is lower in winter than in spring or summer. In the present study, chl a concentrations and BGE values, both of which were estimated for surface waters $(0 \mathrm{~m})$, showed a weak correlation (Fig. $7 \mathrm{a} ; \mathrm{p}<0.06$ ). These results are not inconsistent with the relationship derived by del Giorgio \& Cole (2000).

It has been suggested that the $\mathrm{C}: \mathrm{N}$ ratio of $\mathrm{DOM}$ is a controlling factor for the BGE (Cherrier et al. 1996). Amon \& Benner (1996) showed that BGEs were higher

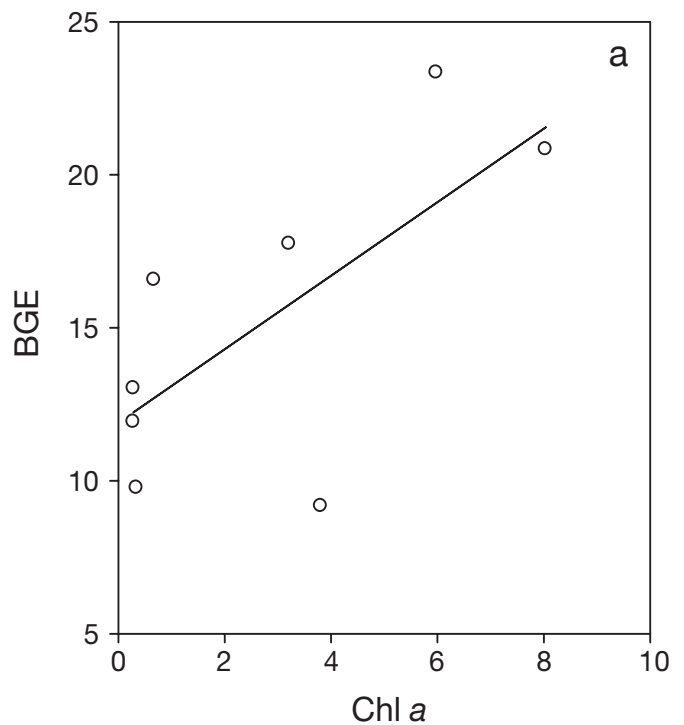

when low-molecular-weight DOM was utilized by bacteria rather than high-molecular-weight DOM. They suggested that the fact that the $\mathrm{C}: \mathrm{N}$ ratio of the highmolecular-weight DOM is higher than that of the lowmolecular-weight DOM causes the former to contribute to a lower BGE. In the present study, however, the relationship between $\mathrm{BGE}$ and the $\mathrm{C}: \mathrm{N}$ ratios of DOM was not statistically significant (Fig. $7 b_{;} \mathrm{R}^{2}=$ $0.19, \mathrm{p}>0.28)$. Cherrier et al. (1996) added model compounds such as glucose and amino acids to their culture so that the $\mathrm{C}: \mathrm{N}$ ratios of the initial DOM were spread over a wide range (3 to 18). As no model compounds were added in the present study, the range of the $\mathrm{C}: \mathrm{N}$ ratios was relatively narrow (13 to 18$)$. The effect of the $C: N$ ratio on BGE may, therefore, be uncertain because of the narrow range of $\mathrm{C}: \mathrm{N}$ ratios employed.

Many studies have made use of seawater culturetype experiments; however, most of these studies assessed seawaters with DOC concentrations of more than 100 to $650 \mu \mathrm{mol} \mathrm{l}^{-1}$ (for reviews, see Søndergaard \& Middelboe 1995, del Giorgio \& Davis 2003), which were much higher than the typical DOC concentrations present in the surface ocean, i.e. 60 to $90 \mu \mathrm{mol} \mathrm{l}^{-1}$ (Benner 2003). Table 4 lists results of previous seawater culture experiments that were performed using surface seawaters with DOC concentrations of $<100 \mu \mathrm{mol}$ $\mathrm{l}^{-1}$. The remarkably slow rates of DOC consumption in the present study $\left(0.08 \pm 0.05\right.$ to $0.18 \pm 0.15 \mu \mathrm{mol} \mathrm{l}^{-1}$ $\mathrm{d}^{-1}$ ) could have been caused by the relatively low DOC concentrations (54 to $68 \mu_{\mathrm{mol}}^{-1}$ ) and the low incubation temperature $\left(5^{\circ} \mathrm{C}\right.$, Table 4$)$. The results for the percentages of DOC consumed in the current study fell within the range of previously reported values. The

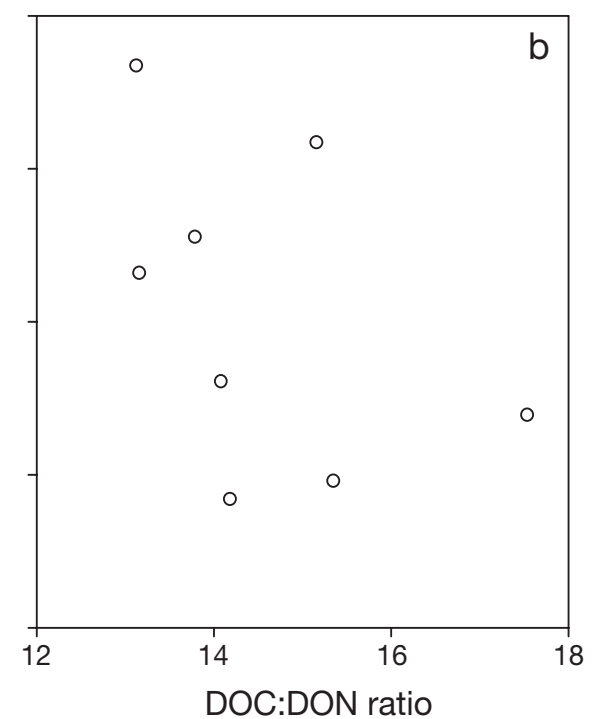

Fig. 7. Relationship between (a) the chlorophyll a (chl a) concentrations and the bacterial growth efficiancy (BGE) and (b) the C:N ratios of the bulk dissolved organic matter (DOM) and the BGE. Solid line is the regression line $\left(y=1.2 x+12 ; R^{2}=0.48, p<0.06\right)$ 
Table 4. Comparisons of the results of seawater culture-type experiments using the surface seawaters with dissolved organic carbon (DOC) concentrations of $<100 \mu \mathrm{mol} \mathrm{l}^{-1}$

\begin{tabular}{|c|c|c|c|c|c|c|c|}
\hline Site & $\begin{array}{l}\text { Initial } \\
\text { DOC } \\
\left(\mu \mathrm{mol} 1^{-1}\right)\end{array}$ & $\begin{array}{l}\text { DOC } \\
\text { consumed } \\
\quad(\%)\end{array}$ & $\begin{array}{l}\text { DOC consumption rate } \\
\left(\mu \mathrm{mol}^{-1} \mathrm{~d}^{-1} \pm \mathrm{SE}\right)^{\mathrm{a}}\end{array}$ & $\begin{array}{l}\text { Duration } \\
\text { of incubation } \\
\text { (d) }\end{array}$ & $\begin{array}{l}\text { Temp- } \\
\text { erature }\left({ }^{\circ} \mathrm{C}\right)\end{array}$ & $\mathrm{n}$ & Source \\
\hline Sargasso Sea & $68-77$ & $0-7.0$ & $0-2.4 \pm 0.24$ & $1.7-7.5$ & $20-26$ & 4 & Carlson \& Ducklow (1996) \\
\hline Middle Atlantic Bight & t $81-94$ & $9.9-14^{\mathrm{b}}$ & $0.54-0.83^{\mathrm{b}}$ & 15 & $19-20$ & 3 & Hopkinson et al. (2002) \\
\hline Eastern North Pacific & $69-72$ & $0-7.0$ & $0-4.4 \pm 2.6$ & $2.5-2.9$ & $11-13$ & 4 & Cherrier et al. (1996) \\
\hline $\begin{array}{l}\text { Subarctic western } \\
\text { North Pacific }\end{array}$ & $54-68$ & $2.1-8.4$ & $0.08 \pm 0.05-0.18 \pm 0.15$ & $14.7-16.6$ & 5 & 8 & This study \\
\hline \multicolumn{8}{|c|}{$\begin{array}{l}\text { aEstimated from the slope of the linear regression of DOC concentrations against time during the incubation period } \\
\text { bEstimated from DOC concentrations on Days } 0 \text { and 15. DOC concentrations on Day } 15 \text { were recalculated from Hopkinson et al } \\
(2002)\end{array}$} \\
\hline
\end{tabular}

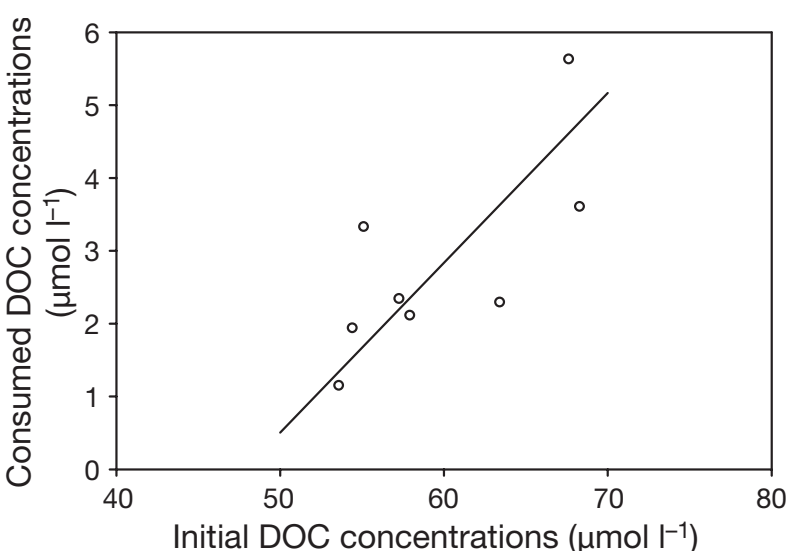

Fig. 8. Relationship between the initial and consumed dissolved organic carbon (DOC) concentrations. Solid line is the regression (Model II) line. Resulting slope $( \pm 95 \%$ confidence interval $)$ is $0.23 \pm 0.16\left(\mathrm{n}=8, \mathrm{R}^{2}=0.54, \mathrm{p}<0.05\right)$. Consumed DOC concentrations are the DOC concentrations that were consumed during 15 to $17 \mathrm{~d}$ incubations of seawater cultures

average percentage of DOC consumed $( \pm \mathrm{SD})$ in these 4 seawater culture experiments (Table 4) was $5.1 \pm$ $4.0 \%$, which is significantly lower than the average percentage for marine environments of $22 \pm 13 \%$ (recalculated from the review by Søndergaard \& Middelboe 1995; Mann-Whitney $U$-test, p < 0.0001); most of the values used in calculating the latter percentage resulted from experiments performed at high DOC concentrations (100 to $650 \mathrm{\mu mol} \mathrm{l}^{-1}$ ). The labile fraction of around $5 \%$ of the whole DOC might be common in the surface ocean, where DOC concentrations are $<100 \mu \mathrm{mol} \mathrm{l} \mathrm{l}^{-1}$.

A property-property plot of DOC versus DOC consumed is shown in Fig. 8. The regression line (Model II) of $y=0.23 x-11$ predicts that labile DOC will become undetectable when the initial DOC concentration is $48 \mathrm{\mu mol} \mathrm{l}^{-1}$. This value is close to the average $( \pm \mathrm{SD})$ concentration at a depth of $500 \mathrm{~m}$ during the observation period ( $46 \pm 2.5 \mu \mathrm{mol} \mathrm{l}{ }^{-1}$; Fig. 2), where most of the DOC consists of semi-labile and refractory fractions.
As the DOC concentrations increased, the DOC consumed also increased. However, the slope of the regression line of the initial DOC and the consumed DOC concentrations was only 0.23 , suggesting that most of the increase in DOC could be attributed to the accumulation of semi-labile to refractory DOC that could be exported by advection and diffusion.

The refractory nature of DOC could explain its seasonal accumulation in surface waters (Carlson 2002). Also, the accumulation of DOC could be explained by a mechanism in which competition for mineral nutrients between bacteria and phytoplankton keeps the bacterial growth low, and bacterial predators keep the bacterial biomass low, so that degradable DOC can accumulate (Thingstad et al. 1997).

According to the latter hypothesis, bacterial utilization of accumulated DOC could be enhanced by reducing the grazing pressure or by addition of limiting nutrient(s) (Carlson 2002). In our seawater-culture experiments, the number of grazers might be negligible as a result of the filtration procedure $(\mathrm{GF} / \mathrm{F})$; this assumption is supported by the bacterial growth curves (Fig. 5). On the other hand, depletion of dissolved inorganic nitrogen (DIN) could restrict utilization of DOC. (In the June experiments, the DIN concentrations were $<0.05 \mu \mathrm{mol} \mathrm{l} \mathrm{l}^{-1}$ and the $\mathrm{PO}_{4}{ }^{3-}$ concentrations were $>0.08 \mathrm{mmol} \mathrm{l}^{-1}$ during the incubation periods; Table 3.) However, the C:N ratios of newly accumulated DOM were around 7.3 (Fig. 6), which implies, at the very least, that the quantity of $\mathrm{N}$ did not limit DOC availability, because bacteria act as regenerators of $\mathrm{NH}_{4}{ }^{+}$when the $\mathrm{C}: \mathrm{N}$ ratio of available substrates is <10:1 (Goldman et al. 1987). Although nitrogenous nutrients were supplied as freshly released DON, this nitrogen did not have a marked effect on the rapid (days to weeks) bacterial consumption of DOC. In the Oyashio region, seasonal DOC accumulation in the surface water could be explained principally by the refractory nature of DOC and/or DON. 
Acknowledgements. We thank the captains and the crews of the RV 'Hokko-maru' and the RV 'Tankai-maru' for their assistance in collecting samples. We also thank K. Chiba, H. Kuno, and M. Masanari for their logistic support.

\section{LITERATURE CITED}

Amon RMW, Benner R (1996) Bacterial utilization of different size classes of dissolved organic matter. Limnol Oceanogr 41:41-51

Azam F, Fenchel T, Field JG, Gray JS, Meyer-Reil LA, Thingstad F (1983) The ecological role of water-column microbes in the sea. Mar Ecol Prog Ser 10:257-263

Banse K (1994) Uptake of inorganic carbon and nitrate by marine plankton and the Redfield ratio. Global Biogeochem Cycles 8:81-84

Benner R (2002) Chemical composition and reactivity. In: Hansell DA, Carlson CA (eds) Biogeochemistry of marine dissolved organic matter. Academic Press, San Diego, CA, p 59-90

Benner R (2003) Molecular indicators of the bioavailability of dissolved organic matter. In: Findlay SEG, Sinsabaugh RL (eds) Aquatic ecosystems. Interactivity of dissolved organic matter. Academic Press, San Diego, CA, p 121-137

Carlson CA (2002) Production and removal processes. In: Hansell DA, Carlson CA (eds) Biogeochemistry of marine dissolved organic matter. Academic Press, San Diego, CA, p 91-151

Carlson CA, Ducklow HW (1996) Growth of bacterioplankton and consumption of dissolved organic carbon in the Sargasso Sea. Aquat Microb Ecol 10:69-85

Carlson CA, Ducklow HW, Michaels AF (1994) Annual flux of dissolved organic carbon from the euphotic zone in the northwestern Sargasso Sea. Nature 371:405-408

Carlson CA, Ducklow HW, Hansell DA, Smith WO (1998) Organic carbon partitioning during spring phytoplankton blooms in the Ross Sea polynya and the Sargasso Sea. Limnol Oceanogr 43:375-386

Carlson CA, Hansell DA, Peltzer ET, Smith WO (2000) Stocks and dyanmics of dissolved and particulate organic matter in the southern Ross Sea, Antarctic. Deep-Sea Res I 47: 3201-3225

Cherrier J, Bauer JE, Druffel ERM (1996) Utilization and turnover of labile dissolved organic matter by bacterial heterotrophs in eastern North Pacific surface waters. Mar Ecol Prog Ser 139:267-279

> Copin-Montégut C (2000) Consumption and production on scales of a few days of inorganic carbon, nitrate and oxygen by the planktonic community: results of continuous measurements at the Dyfamed Station in the northwestern Mediterranean Sea (May 1995). Deep-Sea Res I 47: 447-477

Copin-Montégut G, Avril B (1993) Vertical distribution and temporal variation of dissolved organic carbon in the North-Western Mediterranean Sea. Deep-Sea Res I 40: 1963-1972

Davis J, Benner R (2007) Quantitative estimates of labile and semi-labile dissolved organic carbon in the western Arctic Ocean: A molecular approach. Limnol Oceanogr 52: $2434-2444$

del Giorgio PA, Cole JJ (2000) Bacterial energetics and growth efficiency. In: Kirchman DL (ed) Microbial ecology of the oceans. Wiley-Less, New York, NY, p 289-325

del Giorgio PA, Davis J (2003) Patterns in dissolved organic matter lability and consumption across aquatic ecosystems. In: Findlay SEG, Sinsabaugh RL (eds) Aquatic ecosystems. Interactivity of dissolved organic matter. Academic Press, San Diego, CA, p 399-424

Ducklow H (2000) Bacterial production and biomass in the ocean. In: Kirchman DL (ed) Microbial ecology of the oceans. Wiley-Less, New York, NY, p 85-120

Dugdale RC, Goering JJ (1967) Uptake of new and regenerated forms of nitrogen in primary productivity. Limnol Oceanogr 12:196-206

Eichinger M, Poggiale JC, Van Wambeke F, Lefèvre D, Sempéré R (2006) Modelling DOC assimilation and bacterial growth efficiency in biodegradation experiments: a case study in the Northeast Atlantic Ocean. Aquat Microb Ecol 43:139-151

Eppley RW, Peterson BJ (1979) Particulate organic matter flux and planktonic new production in the deep ocean. Nature 282:677-680

Goldman JC, Caron DA, Dennett MR (1987) Regulation of gross growth efficiency and ammonium regeneration in bacteria by substrate C: N ratio. Limnol Oceanogr 32: 1239-1252

- Hopkinson CS, Vallino JJ (2005) Efficient export of carbon to the deep ocean through dissolved organic matter. Nature 433:142-145

Hopkinson CS, Vallino JJ, Nolin A (2002) Decomposition of dissolved organic matter from the continental margin. Deep-Sea Res II 49:4461-4478

> Hung JJ, Chen CH, Gong GC, Sheu DD, Shiah FK (2003) Distributions, stoichiometric patterns and cross-shelf exports of dissolved organic matter in the East China Sea. Deep-Sea Res II 50:1127-1145

Kähler P, Koeve W (2001) Marine dissolved organic matter: can its C:N ratio explain carbon overconsumption? DeepSea Res I 48:49-62

Karl DM, Hebel DV, Bjökman K, Letelier RM (1998) The role of dissolved organic matter release in the productivity of the oligotrophic North Pacific Ocean. Limnol Oceanogr 43:1270-1286

Kasai H (2000) Seasonal change of nutrients and primary production in the Oyashio region. Bull Plankton Soc Japan 47:116-118 (in Japanese)

Kasai H, Saito H, Kashiwai M, Taneda T and others (2001) Seasonal and interannual variations in nutrients and plankton in the Oyashio region: A summary of a 10-years observation along the A-line. Bull Hokkaido Natl Fish Res Inst 65:55-134

Kawai H (1972) Hydrography of the Kuroshio Extention. In: Stommel H, Yoshida K (eds) Kuroshio. University of Tokyo Press, Tokyo, p 235-352

Kirchman DL, Lancelot C, Fasham M, Legendre L, Radach G, Scott M (1993) Dissolved organic matter in biogeochemical models of the ocean. In: Evans GT, Fasham MJR (eds) Towards a model of ocean biogeochemical processes. Springer-Verlag, Berlin, p 209-225

Körtzinger A, Koeve W, Kähler P, Mintrop L (2001) C: N ratios in the mixed layer during the productive season in the northeast Atlantic Ocean. Deep-Sea Res I 48:661-688

$>$ Lancelot C (1983) Factors affecting phytoplankton extracellular release in the Southern Bight of the North Sea. Mar Ecol Prog Ser 12:115-121

Lomas MW, Bates NR (2004) Potential controls on interannual partitioning of organic carbon during the winter/spring phytoplankton bloom at the Bermuda Atlantic time-series study (BATS) site. Deep-Sea Res I 51:1619-1636

> Longhurst A, Sathyendranath S, Platt T, Caverhill C (1995) An estimate of global primary production in the ocean from satellite radiometer data. J Plankton Res 17: $1245-1271$ 
Mague TH, Friberg E, Hughes DJ, Morris I (1980) Extracellular release of carbon by marine phytoplankton; a physiological approach. Limnol Oceanogr 25:262-279

Mathis JT, Hansell DA, Kadko D, Bates NR, Cooper LW (2007) Determining net dissolved organic carbon production in the hydrographically complex western Arctic Ocean. Limnol Oceanogr 52:1789-1799

McCallister SL, Bauer JE, Canuel EA (2006) Bioreactivity of estuarine dissolved organic matter: A combined geochemical and microbiological approach. Limnol Oceanogr 51:94-100

Nagata T (2000) Production mechanisms of dissolved organic matter. In: Kirchman DL (ed) Microbial ecology of the oceans. Wiley-Less, New York, NY, p 121-152

> Ogawa H, Tanoue E (2003) Dissolved organic matter in oceanic waters. J Oceanogr 59:129-147

> Ogawa H, Fukuda R, Koike I (1999) Vertical distributions of dissolved organic carbon and nitrogen in the Southern Ocean. Deep-Sea Res I 46:1809-1826

Polovina JJ, Howell EA, Abecassis M (2008) Ocean's least productive waters are expanding. Geophys Res Lett 35:L03618. doi:10.1029/2007GL031745

Porter KG, Feig YS (1980) The use of DAPI for identifying and counting aquatic microflora. Limnol Oceanogr 25:943-948

Redfield AC, Ketchum BH, Richards FA (1963) The influence of organisms on the composition of seawaters. In: Hill MN (ed) The sea, Vol 2. Interscience Publishers, New York, NY, p 26-77

Saito H, Kasai H, Kashiwai M, Kawasaki Y, Kono T, Taguchi S, Tsuda A (1998) General description of seasonal variations in nutrients, chlorophyll a, and netplankton biomass along the A-line transect, western subarctic Pacific, from 1990 to 1994. Bull Hokkaido Natl Fish Res Inst 62:1-62

Saito H, Tsuda A, Kasai H (2002) Nutrient and plankton dynamics in the Oyashio region of the western subarctic Pacific Ocean. Deep-Sea Res 49:5463-5486

Sambrotto RN, Savidge G, Robinson C, Boyd P and others (1993) Elevated consumption of carbon relative to nitrogen in the surface ocean. Nature 363:248-250

Sharp JH (1977) Excretion of organic matter by marine phytoplankton: Do healthy cells do it? Limnol Oceanogr 22: 381-399

Smith WOJ, Barber RT, Huntsman SA (1977) Primary production off the coast of northwest Africa: excretion of dissolved organic matter and its heterotrophic uptake. DeepSea Res 24:35-47

Editorial responsibility: Craig Carlson,

Santa Barbara, California, USA
Sohrin R, Sempéré R (2005) Seasonal variation in total organic carbon in the northeast Atlantic in 2000-2001. J Geophys Res 110:C10S90. doi:10.1029/2004JC002731

Søndergaard M, Middelboe M (1995) A cross-system analysis of labile dissolved organic carbon. Mar Ecol Prog Ser 118:283-294

Steinberg DK, Carlson CA, Bates NR, Goldthwait SA, Madin LP, Michaels AF (2000) Zooplankton vertical migration and the active transport of dissolved organic and inorganic carbon in the Sargasso Sea. Deep-Sea Res I 47: 137-158

> Steinberg DK, Cope JS, Wilson SE, Kobari T (2008a) A comparison of mesopelagic mesozooplankton community structure in the subtropical and subarctic North Pacific Ocean. Deep-Sea Res II 55:1615-1635

Steinberg DK, Van Mooy BAS, Buesseler KO, Boyd PW, Kobari T, Karl DM (2008b) Bacterial vs. zooplankton control of sinking particle flux in the ocean's twilight zone. Limnol Oceanogr 53:1327-1338

Strickland JDH, Parsons TR (1972) A practical handbook of seawater analysis. Fish Res Board Can Bull 167

Suzuki R, Ishimaru T (1990) An improved method for the determination of phytoplankton chlorophyll using $\mathrm{N}, \mathrm{N}$ dimethylformamide. J Oceanogr Soc Jpn 46:190-194

Takahashi T, Sutherland SC, Sweeney C, Poisson A and others (2002) Global sea-air $\mathrm{CO}_{2}$ flux based on climatologiacl surface ocean $p \mathrm{CO}_{2}$, and seasonal biological and temperature effects. Deep-Sea Res II 49:1601-1622

Thingstad TF, Hagström $\AA$, Rassoulzadegan F (1997) Accumulation of degradable DOC in surface waters: Is it caused by a malfunctioning microbial loop? Limnol Oceanogr 42:398-404

> Tilstone G, Smyth T, Poulton A, Hutson R (2009) Measured and remotely sensed estimates of primary production in the Atlantic Ocean from 1998 to 2005. Deep-Sea Res II 56:918-930

Toggweiler JR (1993) Carbon overconsumption. Nature 363:210-211

- Williams PJleB (1995) Evidence for the seasonal accumulation of carbon-rich dissolved organic material, its scale in comparison with changes in particulate material and the consequential effect on net C:N assimilation ratios. Mar Chem 51:17-29

Zlotnik I, Dubinsky Z (1989) The effect of light and temperature on DOC excretion by phytoplankton. Limnol Oceanogr 34:831-839

Submitted: July 6, 2009; Accepted: March 11, 2010

Proofs received from author(s): May 17, 2010 